\title{
British political values, attitudes to climate change, and travel behaviour
}

\begin{abstract}
The UK is committed to a sharp reduction of greenhouse gases. Progress towards its goal will depend on whether the public can be persuaded to change their travel behaviour. Using British Social Attitudes 2011 survey data, analyses show that the majority of adults - especially the young and better-educated - believe that climate change is occurring but even concerned believers appear reluctant to modify their behaviour. Policies designed to alter transport habits and induce behaviour change need to take that clear conclusion into account. Without a strong political commitment, substantial change that will significantly mitigate the processes and impact of climate change now appears less likely.
\end{abstract}

\section{KEYWORDS}

Climate change, transport, political values, behavioural change

\section{Introduction}

The UK is committed to a sharp reduction of greenhouse gases (GHG). The emphasis is on market-based policies to achieve that goal but progress will also depend heavily on public commitment and the extent to which concerned citizens can be persuaded to change or modify their behaviour and make personal travel choices that are less environmentally damaging. Drawing on data from the module on climate change beliefs in the 2011 British Social Attitudes survey (BSA: Park et al., 2012), we examine attitudes towards anthropogenic climate change in the British population and the propensity for individual behavioural changes according to socio-demographic characteristics such as age, gender, ethnicity and educational attainment, plus political values and party identification. In general, the young and the better-educated are both more aware of, and more prepared to accept policies designed to mitigate climate change, but individual behavioural adaptation to that end is only likely to occur on a wide scale if it is required through political action; support for such action depends on people's political values, hence the need to study beliefs about climate change and travel behaviour within that context.

\section{Social and Political Context}

The UK government's commitment to a sharp reduction of greenhouse gases (GHG) set out in The Climate Change Act 2008 requires a reduction in emissions by at least 34 per cent from their 1990 levels by 2020, and 80 per cent by 2050. The main mechanism to achieve this will be the EU Emissions Trading Scheme (ETS), alongside a range of mandated market policies designed to encourage energy suppliers to move to renewables and to improve carbon efficiency. Progress will also depend heavily on public opinion and willingness to change behaviour and make choices, including choices about transport and travel that are less environmentally damaging (Giddens, 2011).

The level of greenhouse gases entering the atmosphere is steadily rising and currently there is no known way of removing them, hence the policy emphasis on substantially reducing emission levels. Carbon dioxide (CO2, measured in tons per capita) is the most significant anthropogenic greenhouse gas and the largest single cause of climate change. It is estimated 
that transport alone is responsible for roughly a quarter of all UK CO2 emissions, making it the second biggest contributor to GHG in the UK after energy production (Department of Energy and Climate Change, 2012), and is among the fastest-growing sources (Banister et al., 2012; Chapman, 2007). At the household level, travel accounts for about one-fifth of total CO2 emissions and it is estimated that British citizens, on average, emit over 3 tons of $\mathrm{CO} 2$ each year as a result of their travel behaviour. The total annual average carbon footprint (including direct and indirect embodied emissions) was estimated as close to 17 tons per person, with the atmospheric lifetime of CO2 between 5 and 200 years according to the IPCC (2001). Reports of $\mathrm{CO} 2$ lifetime averages of 100 years are typical (Houghton, 2009), so with the rapid accumulation of those gases in the atmosphere there is the real risk of a runaway greenhouse effect as a result of human-created global warming.

The overwhelming majority of climate scientists and the world's leading scientific bodies agree that anthropogenically-induced climate change is a significant threat to the planet and the human way of life (as illustrated by the Fifth Assessment Reports of the UN Intergovernmental Panel on Climate Change: IPCC, 2014). This global environmental problem is contested in the political arena and wider society, however. Some doubtful Conservative politicians and sceptical commentators in the (conservative) British media have attacked climate change science and sought to undermine the case for climate policy-making (Dunlap and McCright, 2013: on the media and climate change more generally see Painter, 2013, and Boykoff and Smith, 2010). Those 'sceptics' have variously argued either that anthropogenic climate change is scientifically unproven, and/or that the threat posed is exaggerated, and/or even - if it does exist - that little can be done to avert its predicted consequences (Lawson, 2009); recent survey evidence suggests that the British (and American, Leiserowitz et al., 2013) public - for whom, according to Giddens (2011), the significance of climate change is too abstract to grasp - are becoming more sceptical about climate change and concern about global warming is in decline (Humphrey and Scott, 2012).

The research literature suggests that attitudes towards climate change vary (see, for example, Corner et al., 2011; Kellstedt et al., 2008). Men, for example, are less likely than women to see climate change as a serious threat and are less likely to change their behaviour to protect the environment (Tranter, 2012). More educated citizens are more likely than others to believe in the existence of accelerating anthropogenic climate change and many of them are more motivated than others to change their behaviour for the sake of the environment (Whitmarsh, 2011). Such changes are inserted in much wider choice sets, however. Schwanen and Lucas (2011), for example, in a wide-ranging review of automobile use, indicate that people's decisions regarding which transport mode to use for a particular trip will reflect not only their individual characteristics (such as age, sex, income, and education) but also the choice set available to them and the nature of the proposed trip. Whether people are prepared to vary their travel behaviour is thus the outcome of what they term 'complex, dynamic and reciprocal interactions between 'personal' factors and 'external' circumstances, some of which can be influenced by public policies' (Schwannen and Lucas, 2011, 28). Thus although some groups within society might be both more likely to accept the arguments regarding climate change and the impact of $\mathrm{CO} 2$ emissions from various transport modes on its extent, not all of them because of a variety of factors and circumstances - might be willing to alter their own transport behaviour substantially.

There is a tendency for some public opinion research on climate change to be interpreted somewhat simplistically, without due consideration of the role of values (Nisbet, 2013). Public opinion should be understood as the outcome of processes that emerge from social contexts 
and interactions with affective 'schema' (mental organizers) and cognitive 'values' that shape judgements and personal behaviour. Values, as socialized predispositions, provide guidance on making sense of complex problems such as climate change and the proposed actions for dealing with the issue. A considerable body of research explores people's attitudes to climate change and their links to travel behaviour. Those attitudes are generally identified through bespoke instruments designed to measure people's 'motivations, psychological make-up or world views' (Anable, 2005, 65); using a wide-ranging instrument, for example, Anable divided her respondents into six groups: malcontented motorists; complacent car addicts; die-hard drivers; aspiring environmentalists; car-less crusaders; and reluctant riders. These differed on a range of individual characteristics (gender, educational qualifications, income etc.) and in their levels of car use. Although pro-environmental beliefs are a necessary condition for individuals to consider changing their behaviour, however - becoming car-less crusaders rather than die-hard drivers, for example - they may not be sufficient because of a range of obstacles, barriers and impracticalities. Hence the need for public policies not only to advance education and understanding regarding climate change but also to 'nudge' behaviour in a pro-environmental direction (see also Martinsson and Lundqvist, 2010).

Other researchers have similarly used a variety of questionnaire-based instruments to measure environmental values and shown how these are related to preferences, intentions and behaviour (van der Werff, Steg and Keizer, 2013; de Groot and Steg, 2008, 2010), within a wider theoretical framework (Steg et al., 2014). Although some of those studies of environmental values have been set within wider contexts - such as what Steg et al. (2012) term hedonic, egoistic and altruistic values - these have not gone on to explore the links between more general socio-political values, environmental understanding and preparedness to modify behaviour. (For an extensive review covering beliefs about climate change and transport behaviour, see Anable et al., 2006.) In this paper, therefore, we examine attitudes towards anthropogenic climate change in the British population and the propensity for individual behavioural changes according not only to socio-demographic characteristics such as age (on which see Line et al., 2010), gender, and educational attainment, but also from the perspective of political beliefs or core values for which a standard set of scales has been developed and widely used in UK social science (Evans et al., 1996). It is our proposition that political values may help to account for variations in views about climate change, pro-environment behaviour, and the policy changes needed to mitigate and adapt to climate change in important but complex ways; we test for that using a large survey data set which explored British people's attitudes to climate change and possible changes in their transport behaviour to mitigate its effects

\section{Data and analysis}

The British Social Attitudes (BSA) survey series has been conducted since 1983 with over 3,000 interviews annually. Participants are selected using random probability sampling to ensure that the findings are representative of the British population. Over three decades, BSA has covered an extensive range of issues, and the 2011 survey included a module on beliefs about climate change and transport. (Some descriptive analyses of these data - but without any coverage of issues relating to general attitudes - are in Humphrey and Scott, 2012; see also Taylor, 2011.)

\section{Transport use and attitudes to behavioural change}

The initial questions asked respondents about their beliefs regarding climate change, their understanding of its causes, and the level of their concern regarding the impact of transport use 
on its generation. On their answers to the first question, respondents were divided into those who believed in climate change, those who believed that it was happening, but without any human contribution, and those who did not believe in it. (The question asked which of three statements came closest to the respondent's views: 'I don't believe that climate change is taking place'; 'I believe that climate change is taking place but not as a result of human actions'; and I believe that climate change is taking place and is, at least partly, a result of human action'.) That classification is the basis for the analyses reported here; Table 1 shows that the great majority of respondents (77 per cent) believed that climate change is happening, with human contributions; only 7 per cent were climate change deniers, and the remaining 16 per cent believed only in non-anthropogenically-induced climate change. Does that quarter of the population who are, at best, sceptical about anthropogenically-induced climate change differ significantly from the majority group - and in what ways?

Respondents were also asked 'what types of things do you think contribute to climate change?' (a maximum of ten was recorded) and the items they identified were classified by the interviewers (with no prompting) into the following main categories:

- Deforestation;

- Emissions from road transport;

- Emissions from planes;

- Other emissions (factories, power stations etc.);

- Aerosols and CFCs;

- Use of gas and electricity; and

- Methane production.

Table 1 shows the percentage in each of the believer/disbeliever categories who identified each of the causes as contributing to climate change. Not surprisingly, there was a major difference in those percentages across the rows, but some dis-believers nevertheless agreed that the activities, particularly road transport emissions, were contributors. Even among the believers, however, a substantial proportion did not recognise the influence of all of the human-induced contributors. The major identified cause was emissions from road transport, but that percentage was below 70 .

A further question asked respondents how concerned they were regarding transport's contribution to climate change (the question asked how concerned they were, with four options: very concerned; fairly concerned; not very concerned; and not at all concerned). Again, believers - defined by their response to the first question - were much more likely to be concerned than non-believers; 74.5 per cent were either very or fairly concerned, compared to 26.3 per cent of non-believers (Table 2) - with the latter figure somewhat surprising since the beliefs and concerns are, on the surface, contradictory. Similarly, 42.1 per cent of those who believed in climate change but denied human involvement in its generation nevertheless stated that they were very or fairly concerned about road transport's impact.

Having identified respondents' beliefs about climate change, further suites of questions explored their positions towards changing travel behaviour in order to combat climate change. The first four tapped general attitudes to air transport, asking whether respondents agreed or disagreed with the following statements:

- People should be able to travel by plane as much as they like;

- People should travel by plane as much as they like, even if new runways are needed;

- People should travel by plane as much as they like, even if it harms the environment;

- The price of a plane ticket should reflect the environmental damage caused; 
Table 3 tabulates those responses according to their degree of concern about transport's impact. The general pattern is as expected: those most concerned were least likely to express laissez faire attitudes: 21.7 per cent of the very concerned disagreed with the statement that there should be no limits on air transport, for example, as against only 4.3 per cent of those who were not at all concerned. There was less support for complete freedom of use if either it involved building more runways or created environmental damage, but there were still substantial differences, as there were in responses to the final statement - whether ticket prices should reflect environmental damage: the unconcerned were much less likely to approve a user-pays principle than the concerned.

The second suite of general attitude questions comprised five statements asking for agreement or disagreement regarding car use:

- People should be allowed to use their cars as much as they like, even at a cost to the environment;

- People who drive cars that are better for the environment should pay less to use roads;

- For the sake of the environment, car users should pay higher taxes;

- For the environment everyone should reduce how much they use cars; and

- There is no point reducing my car use to help the environment unless others do.

Table 4 shows the same pattern of responses as the previous table. The first statement $-\mathrm{a}$ complete laissez faire policy regarding car use - gained support from only 14.7 per cent of the very concerned respondents compared with 55.2 per cent of the not at all concerned, for example, and 75.2 per cent of the former group agreed that there should be limits on car use compared to 25.4 per cent of the latter. But even among the very concerned there was a large number of free riders, who believed there would be no point in them reducing their own car usage if others didn't too (an implicit statement that there should be legal limits on car use); fully 43.0 per cent of them agreed with that statement.

The last suites of questions related to how individuals would respond themselves, separate from their general positions to transport-use constraints. Table 5 shows the responses to questions on how many short car journeys (of less than two miles) respondents made each week. Whatever their concern about transport's impact on the environment, nevertheless a substantial percentage made several such trips each week (those responding 'never' were those who never travel by car). The potential for reducing car use for short journeys alone was thus substantial.

And were respondents prepared to do that? Table 6 shows the percentages responding positively to four possible travel behaviour changes:

- I am willing to reduce the amount I travel by car to help reduce the impact of climate change;

- I am willing to reduce the amount I travel by plane to help reduce the impact of climate change;

- I am prepared to reduce my speed on the motorway to help reduce my $\mathrm{CO} 2$ emissions;

- Next time I buy a car I would be willing to buy a car with lower CO2 emissions.

As expected, there were major differences across the four groups according to their degree of concern about transport's impact on climate change. In addition, there was one other clear difference: respondents, whatever their degree of concern, were much more prepared to modify their travel behaviour (reducing motorway speeds; buying more environmentally-friendly cars) than they were to restrict it - only just under two-thirds of the very concerned were prepared to reduce their use of air transport, for example, a finding in line with previous, qualitative, research (Hares et al., 2010). 


\section{The correlates of attitudes and behaviour}

The earlier discussion, following a wide literature on the subject, has suggested variations across the population in environmental concerns - with particular reference to age, sex, ethnicity and educational qualifications. Table 7 explores the extent of such variations with regard to the two key variables analysed here - beliefs in climate change and concerns about transport's impact on it - holding the relationships with the four socio-demographic variables constant. (Other variations - by marital status, religion, the presence of children in the household, housing tenure, income, occupation, and employment status - were explored and found to be insubstantial: there were relationships with employment status but as this was collinear with age - older people were more likely to be economically inactive - it was not included as a separate variable. ${ }^{1}$ ) By age, the main difference is between the very old $(75<)$ and the rest of the population; old people were more likely to be climate change deniers and less likely to be concerned about transport's impacts. There was very little difference between males and females in their beliefs regarding climate change, but females were somewhat more likely to be concerned about transport's impact: so were black and other minority ethnic (BME) respondents compared to the white majority. The main differences, as anticipated, reflected educational qualifications: those with none were more than seven times as likely to be climate change deniers as those with degrees for example, and four times as likely to be not at all concerned about transport's impacts on the environment.

It has also been argued that people's general political, social, economic and cultural values are related to their positions on climate change; those with right-wing and authoritarian values would be less likely to favour constraints on individual behaviour than those with more leftwing and/or libertarian views. The BSA survey contained two widely-used sets of Likert-scale attitudinal questions that tapped these value systems (Evans et al., 1996). The first five asked for levels of agreement with statements which tap attitudes that are generally associated with a left-right spectrum of beliefs (those with left-wing attitudes were assumed to agree with the statements):

- Government should redistribute income from the better off to those who are less well off;

- Big business benefits owners at the expense of workers;

- Ordinary working people do not get their fair share of the nation's wealth;

- There is one law for the rich and one for the poor; and

- Management will always try to get the better of employees if it gets the chance.

The second set comprised six statements generally associated with variations in values along a libertarian-authoritarian spectrum (those with authoritarian attitudes were assumed to agree with the statements):

- Young people today don't have enough respect for traditional British values;

- People who break the law should be given stiffer sentences;

- For some crimes, the death penalty is the most appropriate sentence;

- Schools should teach children to obey authority;

- The law should always be obeyed, even if a particular law is wrong;

- Censorship of films and magazines is necessary to uphold moral standards.

For each of these sets we conducted a principal components analysis. In both cases, a single component dominated, as shown by the loadings in Table 8, and a score on each was derived for all respondents. (The responses to some of the statements were recoded so that all were consistent with the assumed scale.) A high positive score on the first component identifies 
somebody with relatively left-wing views; a similar score on the second identifies individuals who are more libertarian than authoritarian in their value systems.

Table 9 shows no substantial differences between respondents' left-right values and whether they believed in climate change, but a considerable difference in whether they were concerned about transport's impact: on average, those who were very concerned about that impact were more left-wing than those who were not very concerned. There were, on the other hand, clearer differences between respondents according to their positions on the second values scale. Libertarians were more likely to be climate-change believers and authoritarians to be nonbelievers, for example; those very concerned about transport's impact were also on average at the libertarian end of the scale whereas those not at all concerned were concentrated towards the authoritarian pole.

\section{Multivariate analyses}

To evaluate the relative importance of the various potential influences on climate change beliefs and transport behaviour, a series of multivariate analyses has been run. After exploration, six independent variables are included: age, sex, educational qualifications, and ethnicity plus the left-right and libertarian-authoritarian scales - others, such as religion and social class, were excluded after preliminary analyses showed no significant relationships. In addition, given the expected strong relationship with qualifications, we also tested for variations among degree-holders according to their values on the two scales using interaction variables, and these are included in the reports where they were significant; the expectation was that graduates with more right-wing and authoritarian views would be less prepared to change their behaviour than their more left-wing and libertarian graduate counterparts.

\section{Beliefs and understanding}

The first regression analysed variations in beliefs about climate change. A multinomial logistic analysis contrasted believers with the other two groups. As anticipated, younger groups were less likely to be either non-believers or non-believers in anthropogenic climate change than members of the oldest generation, although the significant regression coefficients and their related exponents show no steady decrease in climate change believers with age (Table 10); indeed, the most likely non-believers were those aged 55-64 and, perhaps surprisingly, there was no significant difference between the oldest two and the youngest age groups. (Using conventional tests of statistical significance, there are no significant differences between any pair of age groups; the only firm conclusion to be drawn from table 10 is that all age groups aged under 75 were significantly less likely to be non-believers than those aged over 74.) By far the biggest difference revealed is between those with no educational qualifications and those with degrees: the former are nearly six times more likely to be non-believers than the latter (as shown by the exponent of 0.18), and even those with sub-degree qualifications are only half as likely to be climate change deniers as those without qualifications. Degree-holders were also less likely than those without qualifications to believe in non-anthropogenic climate change only.

There were no significant differences in climate change beliefs by either sex or ethnicity, but there were according to position on the libertarian-authoritarian values scale: those towards the libertarian end of that scale were more likely to believe in human-induced climate change and those of a more authoritarian disposition more likely to be sceptical about its existence. Further analyses identified no significant links with the two interaction variables: libertarians with 
degrees were no more likely to believe in climate change than those without; those with strong authoritarian attitudes were no more likely to be non-believers.

Regarding knowledge about the causes of anthropogenic climate change, Table 11 reports analyses of a composite variable relating to the number of positive responses to the seven suggested sources listed in Table 1: the higher the number the greater the range of recognised sources. Of the 3,309 respondents for whom complete data were available, 665 said none of the seven was a source of climate change, whereas only 57 said all seven were. For the analysis, respondents were reduced to three groups: those who identified no sources (no awareness); those identifying 1-3 sources (some awareness); and those identifying four or more sources (high awareness).

Two clear conclusions emerge from this analysis (Table 11): younger people and those with higher qualifications are aware of a greater number of sources of climate change than are both their older contemporaries and those with no qualifications - though, given those differences, females are more likely than males to be aware of a wide range of sources. In addition, those with more libertarian attitudes are on average better-informed than those whose views are closer to the authoritarian pole, especially - as shown by the interaction coefficients libertarians with degrees.

\section{Concerns about transport and climate change}

The next set of multinomial logistic regressions contrasts those who were not at all concerned about the impact of transport on climate change with those who were not very, fairly, or very concerned (Table 12). Again, the clearest differences were across educational qualifications; compared to the unqualified, those with some qualifications and, especially, those with degrees were much more likely to be concerned (nearly four times as likely in the case of those who were very concerned). Again, too, males were both significantly and substantially less likely to be concerned than females (the latter were twice as likely to be very concerned - an exponent of 0.52 ), and older adults were more likely to be concerned than the aged although younger adults were no more likely than those over 74 to be very concerned. (There are substantial exponents exceeding 1.0 for the three youngest age groups, but they are not statistically significant, probably indicative of a collinearity effect because - compared to their older peers - young people are more likely to have degrees: 31.5 per cent of those aged 25-44 in the BSA sample did, compared to 21.8 per cent of those aged 45-54 and 11.8 per cent of 65-74 yearolds.) Finally, those on the left are more likely to be concerned than respondents with more right-wing attitudes and, as the significant interaction coefficients suggest, libertarians with degrees are more likely to be concerned than those without.

\section{Changing behaviour}

Respondents who returned the post-back part of the BSA questionnaire were asked their positions regarding various policies that would constrain plane and transport use. Their answers were recoded so that agreement meant that the respondents adopted the more environmentallyfriendly option (e.g. they were opposed to no constraints on plane travel: Table 3). Of the 951 respondents, 361 had a complete laissez-faire attitude across all four issues, 249 agreed with just one, 167 with two, 11 with three and 65 with all four. For analysis, these were reduced to three groups: those who favoured none of the proposals, 1-2 and 3-4 - with the latter group the most environmentally-friendly. 
Because of the relatively small number of observations, a stepwise regression approach was deployed, and variables with no significant link to the dependent variable excluded. Table 13 shows five clear differences, notably when comparing those who were completely laissez-faire on policy regarding air transport (i.e. gave zero positive answers; the comparator group) with those most in favour of constraints (giving 3-4 positive answers). Those with degrees were twice as likely to favour constraints as those without; those very concerned about transport's impact on the environment were 4.6 times more likely to be in favour of extensive constraints as those with lesser concern; males were less prepared to have constraints on air transport than females; those with left-wing political attitudes and those with libertarian attitudes were also more likely to favour constraints than were those with right-wing and authoritarian attitudes respectively. There were no significant differences across age groups or between ethnic groups.

Regarding constraints on car use, respondents were asked their opinions on five possibilities (Table 4): these were coded so that a positive answer was environmentally-friendly. Of the 951 respondents, just 51 gave a positive answer for none of them, with 222, 250, 256, 146 and 26 for 1-5 environmentally-friendly answers respectively. For the analysis, these were compressed into three groups: 0-1 positive answers, 2-3 and 4-5.

The regression results (Table 14) contain even fewer significant relationships than the previous set with, in particular, no significant differences by either age or qualifications according to the degree to which respondents thought car use should be curbed. (The qualifications variable was retained in later models to allow the exploration of interaction effects.) Apart from the very large differences according to degree of concern regarding transport's impact on the environment, the other significant relationships were with the value scales, with those on the left-wing and libertarians being more likely to prefer constraints on car use than those on the right and authoritarians: males were more likely to favour constraints on car use than females.

Finally, respondents were asked to what extent they were prepared to modify their own travel behaviour, in four ways (Table 5). Of the 918 respondents for whom data were available, 102 were not prepared to change in any way, 125 agreed to make one change and 196 to two; 179 agreed to three of the changes, and 316 to all four. For the regression analysis, these have been reduced to three categories: zero positive answers, 1-2, and 3-4 (Table 15). Females were much more likely to be prepared to change their behaviour than males - the exponent of 0.30 for agreeing to three or four of the proposed changes shows them more than three times as likely to be prepared to make broad changes; there were again no differences by age group. Those with degrees were some 2.7 times more likely to be prepared to make changes than those with lower or no qualifications. Values were also important: both left-wingers and libertarians were more likely to be prepared to make major changes.

\section{Political identification, climate change beliefs and transport behaviour}

The great majority of the respondents to the BSA 2011 survey not only believed in climate change, therefore, but believed that it was human-induced and were sufficiently concerned about transport use as a cause of that change to be prepared to modify their behaviour, to some degree. Were those beliefs and concerns also linked to their political positions, in particular which party they identified with? The respondents were asked - two years after the general election in which the Conservative party leader, who became Prime Minister in a coalition with the Liberal Democrats in 2010, promised the 'greenest government yet' - which party they identified with. Of those who named a party, 1,039 identified with Labour, 926 with the 
Conservatives and 253 the Liberal Democrats; a further 208 identified with one of six minor parties and the remainder either gave no identification or declined to answer.

A multinomial logistic regression analysis contrasted the characteristics of Labour and Liberal Democrat with Conservative identifiers using a typical range of independent variables for such analyses: the other parties were excluded because of their small number of identifiers. This successfully accounted for some 35 per cent of the variation. A second model was then run adding the climate change belief and concern about transport's impact variables, which increased the $\mathrm{R}^{2}$ value to 0.39 . The results of that latter model are in Table 16. Consistent with other research, this shows clear distinctions between Labour and Conservative identifiers on a number of criteria (age, ethnicity, housing tenure, occupational class, and trade union membership) but not between Liberal Democrat and Conservative identifiers (only sex and occupational class were statistically significant). In addition, however, both Labour and Liberal Democrat identifiers were more likely than those who identify with the Conservative party to have left-wing and libertarian values. Furthermore, they were also much more likely to believe in anthropogenically-induced climate change: Conservative identifiers were almost twice as likely as Labour identifiers to be either non-believers or to believe that climate change was happening but was not human-induced, and they were also some six times less likely to believe in climate change than Liberal Democrat identifiers (an exponent of 0.17). Climate change believers therefore identified with the parties of the centre-left rather than that of the right, whose leader had backed away from some of his earlier commitments, ${ }^{2}$ but there was no difference between the three parties' supporters in the extent to which they were concerned about transport's impact on climate change.

Alongside the very substantial differences in respondents' beliefs regarding climate change and attitudes towards its amelioration according to educational qualifications - graduates are by far the most concerned about climate change and the most willing to change their behaviour to combat it - there are therefore also clear differences according to political ideology. The British electorate is clearly divided on two attitudinal dimensions - widely presented as left-right and libertarian-authoritarian - and those divisions are reflected not only in how people vote and respond to political initiatives generally but also, in particular, to what many, including government chief scientists, identify as one of the centuries most pressing issues anthropogenically-induced climate change. Whilst in general it is the young and the more educated who have the greatest concerns regarding that change and are more willing to modify their travel behaviour, those relationships are modified according to their political value systems; among the more educated, those with more right-wing and authoritarian political values are less likely to believe in, and be prepared to respond to, climate change than those whose political values are of the left and libertarian.

\section{Discussion and Conclusions}

The results reported here complement and substantially extend other British work on environmental beliefs and transport behaviour. The majority of adults - especially the young and those with the highest educational qualifications - believe that climate change is occurring and most of them associate that change with human action. Despite that situation, however, many of the believers appear reluctant to modify their behaviour substantially. Policies designed to alter transport habits and induce behaviour change (e.g. Schwanen et al., 2012) need to take that clear conclusion into account: as yet, even those climate-change believers most concerned about transport's contributions are far from fully prepared to make major changes to their own behaviour in order to ensure a sustainable environmental future. 
Moving towards that situation will not be straightforward, however, because the findings here are in some sense contradictory. With the expansion of higher education and generational replacement, a larger proportion of the population should both recognise the existence of human-induced climate change and be prepared to modify their behaviour in order to reduce its impact. But their attitudes towards climate change are likely to be influenced by the media and politicians - media portrayals can have 'far-reaching consequences' in how the scientific issues are portrayed (Boykoff and Smith, 2010, 216), and in turn politicians tend to follow public opinion as crystallised by the media (Soroka and Wlezien, 2010). But, as Painter (2011, 135ff.) argues, the media in western countries are increasingly right-wing in their attitudes sceptical about climate change, unable (unwilling?) to transmit the complex scientific arguments regarding risk and uncertainty (in part by the reduction in the number of specialist science reporters), and so unlikely to promote public understanding of, engagement with and willingness to change behaviour in the light of climate change. Thus the relatively optimistic view presented in the analyses here of attitudes to climate change and behavioural adaptation among the young and the better-educated and those who have both left-wing and libertarian attitudes have to be set against the more pessimistic interpretations of the findings regarding those with more right-wing and authoritarian attitudes. If - as analyses of the media and politicians seeking to win and maintain power suggest - those sceptical attitudes become more prevalent within the population, then, as Whitmarsh's (2011; see also Corner et al., 2012) surveys indicated, substantial change that will significantly mitigate the processes and impact of climate change appears less likely. Without a strong, informed lead people, and especially adolescents (Stevenson et al., 2014), are unlikely to make climate change and its mitigation a high priority personal or political issue (Lorenzoni and Pidgeon, 2006).

\section{Notes}

\footnotetext{
${ }^{1}$ The BSA questionnaire also obtained information on respondents' travel patterns and concerns about a number of other environmental issues - such as the impact on emissions from vehicles - but their incorporation made no significant contributions to the exploratory analyses undertaken before the final set reported here,

2 David Cameron's commitment to lead the 'greenest government ever' (see http://www.theguardian.com/ environment/2010/may/14/cameron-wants-greenest-government-ever) came increasingly under attack from members of his own party over the next four years, however, many of whom opposed subsidies to renewable energy projects during a period of austerity in public spending and their impact on energy prices - so much so that in late 2013 he was quoted as calling for a 'removal of all that green crap' in order to bring bills down and gain popular support in the face of the Labour leader's pledge to freeze energy bills for two years after the 2015 general election (see http://www.theguardian.com/environment/2013/nov/21/david-cameron-green-crapcomments-storm and http://action.labour.org.uk/page/s/energy-calculator).
}

\section{References}

Anable, J. 2005. 'Complacent car addicts' or 'aspiring environmentalists'? Identifying travel behaviour segments using attitude theory. Transport Policy 12, 65-78.

Anable, J., Lane, B. and Kelay, T. 2006. An Evidence Base Review of Public Attitudes to Climate Change and Transport Behaviour. London: Department for Transport.

Banister, D., Schwanen, T., Anable, J. 2012. Introduction to special section on theoretical perspectives on climate change mitigation in transport. Journal of Transport Geography 24, 467-470. 
Boykoff, M. I. and Smith, J. 2010. Media presentations of climate change. In C. Lever-Tracy (ed.) Routledge Handbook of Climate Change and Society, London, Routledge, 210218.

Chapman, L. 2007. Transport and climate change: a review. Journal of Transport Geography 15, 354-367.

Corner, A., Whitmarsh, L. and Xenias, D. 2012. Uncertainty, scepticism and attitudes towards climate change: biased assimilation and attitude polarisation. Climate Change 114, 463478.

Corner, A., Venables, D., Spence, A., Poortinga, W., Demski, C. and Pidgeon, N. 2011. Nuclear power, climate change and energy security: exploring British public attitudes. Energy Policy 39, 4823-4833.

de Groot, J. I. M., Steg, L. 2008. Value orientations to explain beliefs related to environmental significant behaviour: how to measure egoistic, altruistic, and biospheric value orientations. Environment and Behavior 40, 330-354.

de Groot, J. I. M., Steg, L. 2010. Relationships between value orientations, self-determined motivational types and pro-environmental behavioural intentions. Journal of Environmental Psychology 30, 368-378.

Department of Energy and Climate Change 2012. 2012 UK Greenhouse Gas Emissions, Provisional Figures and 2011 UK Greenhouse Gas Emissions, Final Figures By Fuel Type and End-User - available at https:/www.gov.uk/government/uploads/system/ uploads_attachment_data/file/193414/280313_ghg_national_statistics_release_2012 provisional.pdf (accessed 18 March 2014)

Dunlap, R. E., McCright, A. M. 2013. Organized climate change denial, in Dryzek, J. S., Norgaard, R. A., Schlosberg, D. (eds.) The Oxford Handbook of Climate Change and Society, Oxford, Oxford University Press, 144-160.

Evans, G., Heath, A., Lalljee, M. 1996. Measuring left-right and libertarian-authoritarian vales in the British electorate, British Journal of Sociology 47 (1), 93-112.

Giddens, A. 2011. The Politics of Climate Change (second edition), Cambridge, Polity Press.

Hares, A., Dickinson, J., Wilkes, K. 2010. Climate change and the air travel decisions of UK tourists. Journal of Transport Geography 18, 466-473.

Houghton, J. 2009. Global Warming: the Complete Briefing (fourth edition), Cambridge, Cambridge University Press.

Humphrey, A., Scott, A. (2012) Transport: how far will people go to tackle climate change? In Park, A., Clery, E., Curtice, J., Phillips, M., Utting, D. (eds.) British Social Attitudes: the $29^{\text {th }}$ Report, London, Natcen Social Research, 64-79. 
IPCC 2001. Climate Change 2001: The Scientific Basis. Contribution of Working Group I to the Third Assessment Report of the Intergovernmental Panel on Climate Change, Cambridge, Cambridge University Press.

IPCC 2014. Climate Change 2014. Synthesis Report, Cambridge, Cambridge University Press.

Kellstedt, P. M., Zahran, S. and Vedlitz, A. 2008. Personal efficacy, the information environment and attitudes towards global warming and climate change in the United States. Risk Analysis 28, 113-126.

Lawson, N. 2009. An Appeal to Reason: a Cool Look at Global Warming. Dickworth: London.

Lieserowitz, A. A., Maibach, E. W., Roser-Renouf, C., Smith, N., Dawson, E. 2013. Climategate, public opinion, and the loss of trust, American Behavioral Scientist 57 (6), 818-837.

Line, T., Chatterjee, K., Lyons, G. 2010. The travel behaviour intentions of young people in the context of climate change. Journal of Transport Geography 18, 238-246.

Lorenzoni, I. and Pidgeon, N. F. 2006. Public views on climate change: European and USA perspectives. Climate Change 77, 73-95.

Martinsson, J., Lundqvist, L. J. 2010. Ecological citizenship: coming out 'clean' without turning 'green'. Environmental Politics 19, 518-537.

Nisbet, M. C. 2013. Public opinion and participation, in Dryzek, J. S., Norgaard, R. A., Schlosberg, D. (eds.) The Oxford Handbook of Climate Change and Society, Oxford, Oxford University Press, 355-368.

Painter, J. 2013. Climate Change in the Media: Reporting Risk and Uncertainty, London, I. B. Tauris.

Park, A., Clery, E., Curtice, J., Phillips, M., Utting, D. (eds.) 2012. British Social Attitudes: the $29^{\text {th }}$ Report, London, Natcen Social Research.

Schwanen, T., Banister, D., Anable, J. 2012. Rethinking habits and their role in behaviour change: the case of low-carbon mobility. Journal of Transport Geography 24, 522-532.

Schwanen, T., Lucas, K. 2011. Understanding auto motives. In Lucas, K., Blumenberg, E., Weinberger, R. (eds.) Auto Motives: Understanding Car Use Behaviours, London, Emerald, 3-38.

Soroka, S. N. and Wlezien, C. (2010) Degrees of Democracy: Politics, Public Opinion and Policy. Philadelphia: Temple University Press.

Steg, L., Bolderdijk, J. W., Keizer, K., Perlaviciute, G. 2014. An integrated framework for encouraging pro-environental behaviour: the role of values, situational factors, and goals. Journal of Environmental Psychology 38, 104-115. 
Steg, L. Perlaviciute, G., va der Werff, E., Lurvink, J. 2014. The significance of hedonic values for environmentally relevant attitudes, preferences and actions. Environment and Behavior 46, 163-192.

Stevenson, K., Peterson, M. N., Bondell, H. D., Moore, S. E. and Carrier, S. J. Overcoming scepticism with education: interacting influences of worldview and climate change knowledge on perceived climate change risk among adolescents. Climatic Change 126, 293-304.

Taylor, E. 2011. Concern about climate change: a paler shade of green? In Park, A., Clery, E., Curtice, J., Phillips, M. and Utting, D. (eds.) British Social Attitudes: the $28^{\text {th }}$ Report. London: SAGE, 91-110.

Tranter, B. 2014. Social and political influences on environmentalism in Australia, Journal of Sociology, 50, 331-348.

van der Werff, E., Steg, L., Keizer, K. 2013. The value of environmental self-identity: the relationship between biospheric values, environmental self-identity and environmental preferences, intentions and behaviour. Journal of Environmental Psychology 34, 55-63.

Whitmarsh, L. 2011. Scepticism and uncertainty about climate change: dimensions, determinants and change over time. Global Environmental Change 21, 690-700. 
Table 1. Beliefs about climate change and its sources (per cent of column totals)

\begin{tabular}{lrrr} 
& \multicolumn{3}{c}{ Climate Change Belief } \\
Source & NB & BNH & B \\
Deforestation & 4.5 & 10.1 & 29.1 \\
Road transport & 14.9 & 31.3 & 69.3 \\
Air transport & 6.8 & 20.2 & 46.1 \\
Other emissions & 11.2 & 29.7 & 60.6 \\
Aerosols/CFCs & 4.0 & 5.4 & 12.7 \\
Gas/electricity & 1.8 & 6.2 & 18.1 \\
Methane & 3.1 & 8.5 & 20.3 \\
\hline $\mathrm{N}$ & 223 & 516 & 2,521
\end{tabular}

Key: NB - non-believers; $\mathrm{BNH}$ - believers that there is climate change but without human involvement; $\mathrm{B}$ - believers that there is human-induced climate change. 
Table 2. Beliefs about climate change and the impact of transport (per cent of column totals)

\begin{tabular}{lrrr} 
& \multicolumn{3}{c}{ Climate Change Belief } \\
Source & NB & BNH & B \\
\hline Very & 6.8 & 9.7 & 23.2 \\
Fairly & 19.5 & 32.4 & 51.3 \\
Not very & 38.0 & 41.1 & 21.3 \\
Not at all & 35.7 & 16.8 & 4.2 \\
\hline N & 223 & 513 & 2,500
\end{tabular}

Key: NB - non-believers; $\mathrm{BNH}$ - believers that there is climate change but without human involvement; $\mathrm{B}$ - believers that there is human-induced climate change. 
Table 3. Degree of concern regarding transport's impact on climate change and attitudes to travel behaviour (percentages of column totals: the percentages in each block do not sum to 100 because of those who expressed no opinion)

\begin{tabular}{lrrrr} 
& \multicolumn{4}{c}{ Degree of Concern } \\
& $\mathrm{V}$ & $\mathrm{F}$ & $\mathrm{NV}$ & NAA \\
\hline Travel by plane as much as they like & & & & \\
Agree strongly & 10.3 & 10.3 & 16.6 & 20.6 \\
Agree & 41.4 & 48.1 & 54.7 & 55.9 \\
Neither agree/disagree & 22.7 & 25.5 & 18.3 & 13.2 \\
Disagree & 21.2 & 8.9 & 4.0 & 2.9 \\
Disagree strongly & 0.5 & 0.5 & 0.4 & 1.4
\end{tabular}

Travel by plane as much as they like even if new runways needed

$\begin{array}{lrrrr}\text { Agree strongly } & 3.9 & 6.3 & 5.2 & 15.2 \\ \text { Agree } & 22.0 & 25.6 & 41.4 & 50.0 \\ \text { Neither agree/disagree } & 25.4 & 31.2 & 28.1 & 10.6 \\ \text { Disagree } & 34.6 & 25.2 & 15.7 & 16.7 \\ \text { Disagree strongly } & 8.3 & 4.0 & 2.0 & 1.5\end{array}$

Travel by plane as much as they like even if harms environment

$\begin{array}{lrrrr}\text { Agree strongly } & 1.0 & 3.5 & 2.4 & 11.9 \\ \text { Agree } & 6.3 & 13.3 & 21.0 & 23.9 \\ \text { Neither agree/disagree } & 24.9 & 28.1 & 42.3 & 25.4 \\ \text { Disagree } & 42.9 & 38.4 & 24.6 & 22.4 \\ \text { Disagree strongly } & 20.0 & 8.6 & 2.4 & 6.0\end{array}$

Ticket price should reflect damage

\begin{tabular}{lrrrr} 
Agree strongly & 17.7 & 4.9 & 4.9 & 7.6 \\
Agree & 35.5 & 32.9 & 32.4 & 25.8 \\
Neither agree/disagree & 17.2 & 30.6 & 22.7 & 18.2 \\
Disagree & 19.7 & 18.9 & 26.7 & 28.5 \\
Disagree strongly & 4.4 & 4.9 & 6.5 & 13.6 \\
\hline & 203 & 428 & 247 & 66
\end{tabular}

Key to degree of concern: V - Very; F - Fairly; NV - Not Very; NAA - Not At All. 
Table 4. Degree of concern regarding transport's impact on climate change and attitudes to travel behaviour (percentages of column totals: the percentages in each block do not sum to 100 because of those who expressed no opinion)

People should use cars as much as they like

$\begin{array}{lrrrr}\text { Agree strongly } & 3.4 & 2.6 & 3.2 & 16.4 \\ \text { Agree } & 11.3 & 19.3 & 36.9 & 38.8 \\ \text { Neither agree/disagree } & 22.5 & 38.0 & 38.2 & 19.4 \\ \text { Disagree } & 41.2 & 29.8 & 15.7 & 17.9 \\ \text { Disagree strongly } & 17.2 & 4.0 & 0.8 & 1.5\end{array}$

People with environmentally-friendly cars should pay less for road use

$\begin{array}{lrrrr}\text { Agree strongly } & 5.4 & 1.9 & 0.18 & 0.0 \\ \text { Agree } & 23.2 & 10.0 & 3.2 & 4.5 \\ \text { Neither agree/disagree } & 16.7 & 21.2 & 16.2 & 25.4 \\ \text { Disagree } & 42.9 & 45.5 & 50.6 & 44.8 \\ \text { Disagree strongly } & 10.3 & 15.9 & 23.1 & 20.9\end{array}$

Differential road charges

Agree strongly

$\begin{array}{llll}22.5 & 14.5 & 8.0 & 7.5\end{array}$

Agree

46.1

46.0

$43.0 \quad 34.3$

Neither agree/disagree

16.2

21.7

$22.5 \quad 28.4$

Disagree

8.8

10.3

16.1

14.9

Disagree strongly

2.0

2.1

2.0

7.5

All should reduce car use

Agree strongly

$\begin{array}{llll}21.5 & 7.2 & 5.2 & 1.5\end{array}$

Agree

53.7

52.3

32.7

23.9

Neither agree/disagree

13.7

24.2

33.5

26.9

Disagree

9.8

19.8

34.3

Disagree strongly

2.4

0.9

2.0

9.0

Free rider on car use

Agree strongly

12.2

6.0

15.3

6.0

Agree

31.7

37.2

40.7

34.3

Neither agree/disagree

9.3

24.2

22.2

32.8

Disagree

26.8

21.4

12.5

9.0

$\mathrm{N}$

15.1

2.8

1.6

3.0

Key to degree of concern: V - Very; F - Fairly; NV - Not Very; NAA - Not At All. 
Table 5. Degree of concern regarding transport's impact on climate change and current road use (percentages of column totals: the percentages in each block do not sum to 100 because of those who expressed no opinion)

\begin{tabular}{crrrr} 
& \multicolumn{4}{c}{ Degree of Concern } \\
& $\mathrm{V}$ & $\mathrm{F}$ & $\mathrm{NV}$ & NAA \\
\hline Number of short car journeys per week & & & & \\
0 & 19.4 & 17.8 & 18.0 & 23.1 \\
$1-2$ & 28.3 & 23.0 & 22.7 & 21.7 \\
$3-5$ & 15.6 & 23.7 & 18.6 & 6.3 \\
$6-10$ & 7.0 & 12.9 & 15.4 & 9.1 \\
$11+$ & 4.9 & 4.4 & 11.2 & 8.4 \\
Never & 18.9 & 13.0 & 9.4 & 21.0 \\
\hline $\mathrm{N}$ & 371 & 870 & 501 & 143
\end{tabular}

Key to degree of concern: V - Very; F - Fairly; NV - Not Very; NAA - Not At All. 
Table 6. Degree of concern regarding transport's impact on climate change and willingness to change travel behaviour (percentages of column totals: the percentages in each block do not sum to 100 because of those who expressed no opinion)

Degree of Concern

\begin{tabular}{lcrrr} 
& V & F & NV & NAA \\
\hline Reduce amount of car travel & 79.8 & 58.2 & 36.1 & 22.8 \\
Reduce the amount of plane travel & 64.7 & 52.0 & 27.0 & 16.7 \\
Prepared to reduce motorway speed & 93.4 & 78.9 & 55.6 & 24.4 \\
Buy a car with lower CO2 emissions & 97.8 & 90.5 & 73.8 & 47.4 \\
\hline N & 183 & 402 & 252 & 78
\end{tabular}

Key to degree of concern: V - Very; F - Fairly; NV - Not Very; NAA - Not At All. 
Table 7. Age, sex, ethnicity, educational qualifications and climate change attitudes (percentage of row totals)

\begin{tabular}{lrrrrrrr} 
& \multicolumn{6}{c}{ Climate Change Beliefs } & \multicolumn{5}{c}{ Concern about Transport's Impact } \\
& NB & BNH & B & V & F & NV & NAA \\
\hline Age group & & & & & & & \\
$15-24$ & 7 & 18 & 75 & 22 & 41 & 29 & 9 \\
$25-44$ & 5 & 12 & 83 & 20 & 50 & 23 & 7 \\
$45-54$ & 6 & 16 & 78 & 18 & 47 & 25 & 10 \\
$55-64$ & 6 & 16 & 78 & 20 & 46 & 27 & 7 \\
$65-74$ & 7 & 21 & 72 & 22 & 43 & 26 & 9 \\
$75<$ & 16 & 21 & 63 & 17 & 35 & 31 & 17 \\
Sex & & & & & & & \\
$\quad$ Male & 7 & 17 & 76 & 19 & 42 & 29 & 10 \\
Female & 7 & 15 & 79 & 21 & 49 & 23 & 7 \\
Ethnicity & & & & & & & \\
$\quad$ White & 7 & 16 & 77 & 18 & 47 & 26 & 9 \\
BME & 5 & 16 & 79 & 33 & 40 & 21 & 6 \\
Educational qualifications & & & & & & & \\
$\quad$ Degree & 2 & 11 & 87 & 24 & 48 & 24 & 4 \\
$\quad$ Sub-degree & 5 & 16 & 79 & 19 & 48 & 25 & 8 \\
$\quad$ None & 15 & 19 & 66 & 17 & 40 & 28 & 16
\end{tabular}

Keys: Climate Change Beliefs: NB - Non-Believer; BNH - Believer but No Human

Contribution; B - Believer: Degree of Concern: V - Very; F - Fairly; NV - Not Very; NAA

- Not At All. 
Table 8. Loadings on the principal components

\section{Left-Right}

Redistribute income

Owners benefit

Fair shares of wealth

One law for the rich

Management wins
Libertarian-Authoritarian

0.73

0.81

0.86

0.85

0.83
Young disrespect

0.79

Stiffer sentences

Death penalty

Authority at schools

Law always obeyed

Censorship necessary
0.84

0.72

0.84

0.71

0.72 
Table 9. Mean values on the two attitudinal components and climate change attitudes.

\begin{tabular}{lrrrrrrr} 
& \multicolumn{3}{c}{ Climate Change Beliefs } & \multicolumn{4}{c}{ Concern about Transport's Impact } \\
& NB & BNH & B & V & F & NV & NAA \\
\hline Left-right & 0.01 & -0.05 & 0.02 & -0.19 & 0.01 & 0.15 & 0.04 \\
Libertn.-authoritn. & -0.19 & -0.20 & 0.10 & 0.15 & 0.05 & -0.01 & -0.14
\end{tabular}

Keys: Climate Change Beliefs: NB - Non-Believer; BNH - Believer but No Human Contribution; B - Believer: Degree of Concern: V - Very; F - Fairly; NV - Not Very; NAA - Not At All. 
Table 10. Multinomial logistic regression analysis of climate change beliefs (comparator: believer)

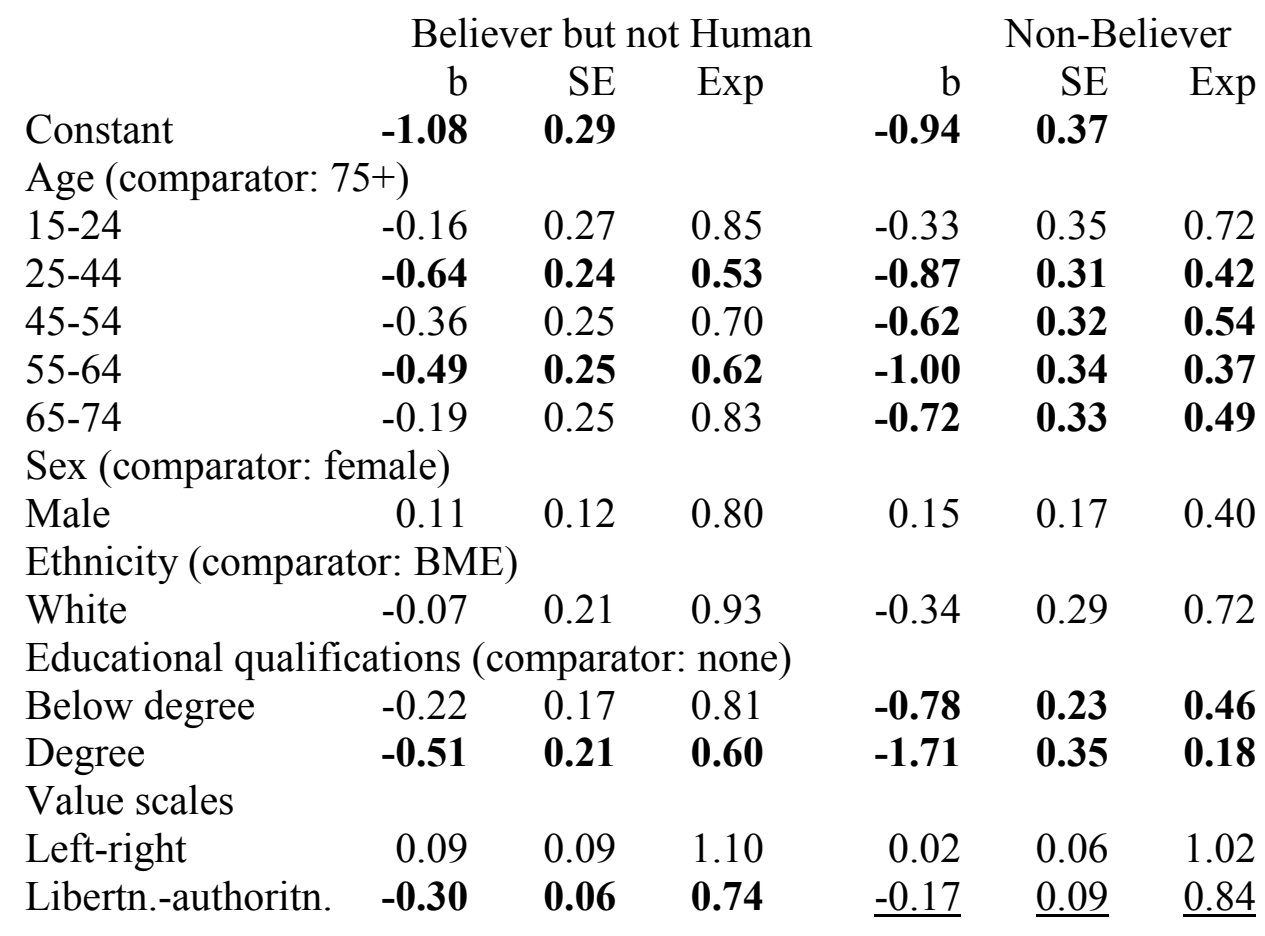

Coefficients in bold are significant at the 0.05 level or better; those underlined are significant between 0.05-0.10. 
Table 11. Multinomial logistic regression analysis of awareness of the impact of various causes of climate change (comparator: no awareness).

\begin{tabular}{|c|c|c|c|c|c|c|}
\hline & \multicolumn{3}{|c|}{ Some Awarness } & \multicolumn{3}{|c|}{ High Awareness } \\
\hline & $\mathrm{b}$ & SE & $\operatorname{Exp}$ & $\mathrm{b}$ & SE & Exp \\
\hline Constant & 1.23 & 0.31 & & -1.24 & 0.44 & \\
\hline \multicolumn{7}{|c|}{ Age (comparator: $75+$ ) } \\
\hline $15-24$ & 0.85 & 0.26 & 2.34 & 1.10 & $\mathbf{0 . 4 0}$ & 3.00 \\
\hline $25-44$ & 0.71 & 0.21 & 2.04 & 1.47 & 0.35 & 4.37 \\
\hline $45-54$ & 0.33 & 0.22 & 1.39 & 0.91 & 0.36 & 2.45 \\
\hline $55-64$ & $\underline{0.39}$ & $\underline{0.22}$ & 1.47 & 1.13 & 0.36 & 3.06 \\
\hline $65-74$ & -0.11 & $\overline{0.22}$ & 0.90 & 0.43 & 0.37 & 1.54 \\
\hline \multicolumn{7}{|c|}{ Sex (comparator: female) } \\
\hline Male & 0.07 & 0.11 & 1.07 & -0.32 & 0.14 & 0.73 \\
\hline \multicolumn{7}{|c|}{ Ethnicity (comparator: BME) } \\
\hline White & -0.79 & 0.26 & 0.45 & -0.36 & 0.31 & 0.70 \\
\hline \multicolumn{7}{|c|}{ Educational qualifications (comparator: none) } \\
\hline Below degree & 0.38 & 0.15 & 1.46 & 0.73 & 0.22 & 2.04 \\
\hline Degree & 0.79 & 0.21 & 2.19 & 1.43 & 0.27 & 4.19 \\
\hline \multicolumn{7}{|l|}{ Value scales } \\
\hline Left-right & -0.03 & 0.06 & 0.97 & -0.01 & 0.08 & 0.99 \\
\hline Libertn-authoritn. & 0.04 & 0.07 & 1.04 & 0.17 & 0.08 & 1.19 \\
\hline \multicolumn{7}{|c|}{ Interactions with degree } \\
\hline Left-right & -0.12 & 0.15 & 0.39 & -0.40 & -0.17 & 0.67 \\
\hline Libertn-authoritn. & 0.36 & 0.16 & 1.44 & 0.35 & 0.18 & 1.43 \\
\hline
\end{tabular}

Coefficients in bold are significant at the 0.05 level or better; those underlined are significant between $0.05-0.10$. 
Table 12. Multinomial logistic regression analysis of degree of concern regarding transport's impact on climate change (comparator: not at all concerned)

\begin{tabular}{|c|c|c|c|c|c|c|c|c|c|}
\hline \multirow[t]{2}{*}{ Degree of concern } & \multicolumn{3}{|c|}{ Not Very } & \multicolumn{3}{|c|}{ Fairly } & \multicolumn{3}{|c|}{ Very } \\
\hline & $b$ & $\mathrm{SE}$ & $\operatorname{Exp}$ & $\mathrm{b}$ & SE & $\operatorname{Exp}$ & $\mathrm{b}$ & SE & $\operatorname{Exp}$ \\
\hline Constant & 0.58 & 0.41 & & 0.72 & 0.40 & & 1.07 & 0.42 & \\
\hline \multicolumn{10}{|c|}{ Age (comparator: $75+$ ) } \\
\hline $15-24$ & 0.59 & 0.37 & 1.80 & $\underline{0.60}$ & $\underline{0.36}$ & $\underline{1.82}$ & 0.50 & 0.39 & 1.64 \\
\hline $25-44$ & 0.25 & 0.31 & 1.28 & $\overline{0.94}$ & $\overline{0.30}$ & $\overline{2.58}$ & 0.27 & 0.33 & .31 \\
\hline $45-54$ & 0.26 & 0.33 & 1.30 & 0.78 & 0.32 & 2.19 & 0.18 & 0.35 & .20 \\
\hline $55-64$ & 0.76 & 0.34 & 2.13 & 1.18 & 0.33 & 3.24 & 0.74 & 0.36 & 2.09 \\
\hline $65-74$ & $\underline{0.59}$ & $\underline{0.34}$ & $\underline{1.81}$ & 0.97 & 0.33 & 2.64 & 0.79 & 0.36 & 2.20 \\
\hline \multicolumn{10}{|c|}{ Sex (comparator: female) } \\
\hline Male & -0.14 & 0.17 & 0.87 & -0.63 & 0.16 & $\mathbf{0 . 5 3}$ & -0.65 & 0.18 & .52 \\
\hline \multicolumn{10}{|c|}{ Ethnicity (comparator: BME) } \\
\hline White & -0.16 & 0.33 & 0.85 & -0.10 & 0.32 & 0.91 & -0.93 & 0.32 & .39 \\
\hline \multicolumn{10}{|c|}{ Educational qualifications (comparator: none) } \\
\hline Below degree & $\underline{0.45}$ & $\underline{0.23}$ & $\underline{1.57}$ & 0.72 & 0.22 & 2.05 & 0.61 & 0.25 & 1.83 \\
\hline Degree & $\overline{0.94}$ & $\overline{\mathbf{0 . 3 2}}$ & $\overline{2.55}$ & 1.13 & 0.31 & 3.84 & 1.35 & 0.33 & 3.84 \\
\hline \multicolumn{10}{|l|}{ Value scales } \\
\hline Left-right & 0.18 & 0.10 & 1.08 & $\underline{-0.15}$ & $\underline{0.09}$ & $\underline{0.86}$ & -0.25 & 0.10 & 0.78 \\
\hline Libertn-authoritn. & 0.03 & 0.10 & 1.03 & 0.04 & $\overline{0.09}$ & $\overline{1.13}$ & 0.13 & 0.10 & 114 \\
\hline \multicolumn{10}{|c|}{ Interactions with degree } \\
\hline Left-right & 0.02 & 0.22 & 1.03 & 0.13 & 0.22 & 1.13 & -0.13 & 0.23 & 0.0 \\
\hline Libertn-authoritn. & 0.31 & 0.25 & 1.37 & 0.60 & 0.24 & 1.82 & 0.58 & 0.25 & 1 \\
\hline
\end{tabular}

Coefficients in bold are significant at the 0.05 level or better; those underlined are significant between 0.05-0.10. 
Table 13. Multinomial logistic regression of attitudes towards potential policies constraining plane transport (comparator: opposed to all constraints)

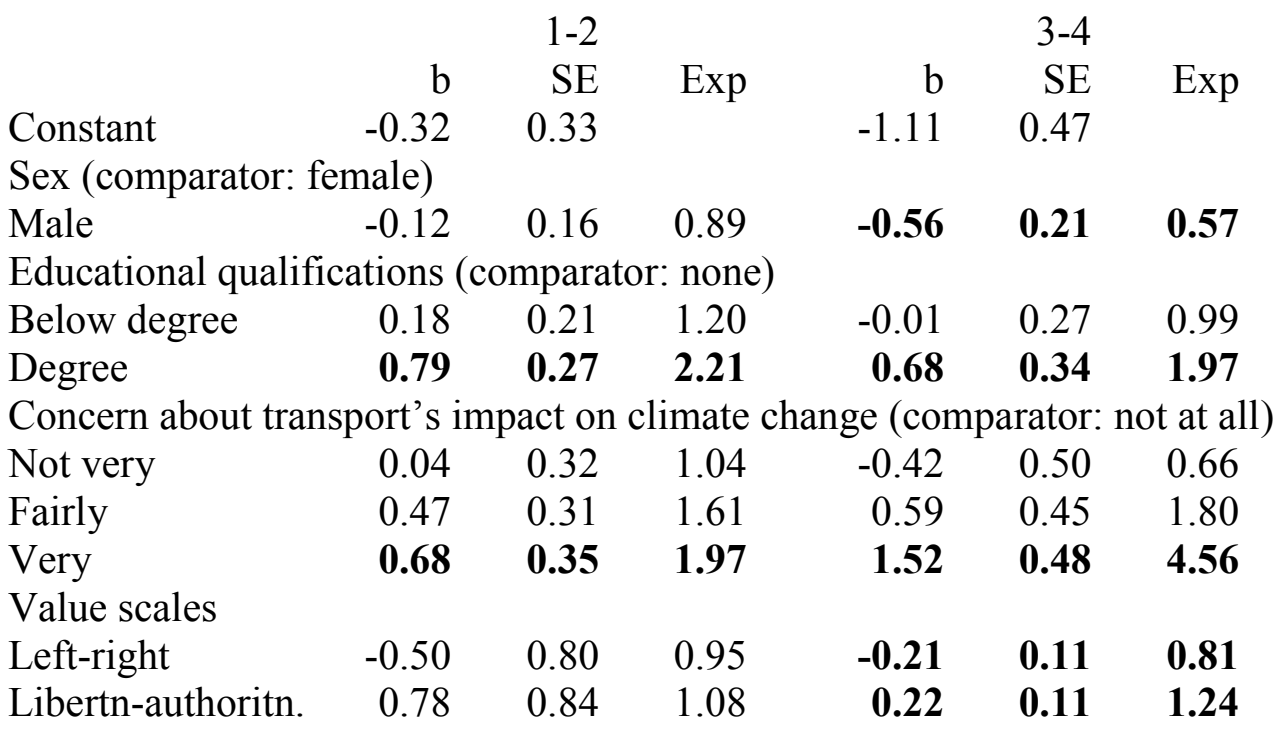

Coefficients in bold are significant at the 0.05 level or better; those underlined are significant between 0.05-0. 
Table 14. Multinomial logistic regression of attitudes towards potential policies constraining car transport (comparator: opposed to most constraints)

\begin{tabular}{lrrrrrr} 
& \multicolumn{3}{c}{$2-3$} & & $4-5$ & \\
& $\mathrm{~b}$ & $\mathrm{SE}$ & $\operatorname{Exp}$ & $\mathrm{b}$ & $\mathrm{SE}$ & $\mathrm{Exp}$ \\
Constant & -0.35 & 0.31 & & -2.97 & 0.79 & \\
Educational qualifications (comparator: none) & & & \\
Below degree & -0.04 & 0.22 & 0.96 & 0.05 & 0.31 & 1.05 \\
Degree & 0.44 & 0.30 & 1.55 & 0.50 & 0.41 & 1.65
\end{tabular}

Concern about transport's impact on climate change (comparator: not at all)

$\begin{array}{lllllll}\text { Not very } & \mathbf{0 . 7 3} & \mathbf{0 . 3 1} & \mathbf{2 . 0 7} & 0.94 & 0.82 & 2.55\end{array}$

$\begin{array}{lllllll}\text { Fairly } & 1.20 & 0.30 & 3.32 & 2.65 & 0.78 & 14.15\end{array}$

$\begin{array}{lllllll}\text { Very } & 1.79 & 0.37 & 5.98 & 3.80 & 0.80 & 44.62\end{array}$

Value scales

$\begin{array}{lllllll}\text { Left-right } & \mathbf{- 0 . 1 9} & \mathbf{0 . 1 0} & \mathbf{0 . 8 3} & \underline{-0.25} & \underline{0.13} & \underline{0.78} \\ \text { Libertn-authoritn } & -0.04 & 0.10 & 0.96 & -0.01 & 0.13 & 1.00\end{array}$

Interactions with degree

$\begin{array}{lllllll}\text { Left-right } & -0.07 & 0.21 & 0.91 & -0.46 & 0.28 & 0.64\end{array}$

$\begin{array}{lllllll}\text { Libertn-authoritn. } & 0.23 & 0.25 & 1.26 & \mathbf{0 . 7 1} & \mathbf{0 . 3 0} & \mathbf{2 . 0 4}\end{array}$

Coefficients in bold are significant at the 0.05 level or better; those underlined are significant between $0.05-0.10$. 
Table 15. Multinomial logistic regression of willingness to constrain own transport use (comparator: opposed to all constraints)

\begin{tabular}{|c|c|c|c|c|c|c|}
\hline \multirow[t]{2}{*}{ Number of changes } & \multicolumn{3}{|c|}{$1-2$} & \multicolumn{3}{|c|}{$3-4$} \\
\hline & $\mathrm{b}$ & $\mathrm{SE}$ & $\operatorname{Exp}$ & $\mathrm{b}$ & SE & Exp \\
\hline Constant & 2.34 & 0.92 & & 3.58 & 0.90 & \\
\hline \multicolumn{7}{|c|}{ Sex (comparator: female) } \\
\hline Male & -0.84 & 0.29 & 0.43 & -1.19 & 0.28 & 0.30 \\
\hline \multicolumn{7}{|c|}{ Ethnicity (comparator: BME) } \\
\hline White & -0.88 & 0.87 & 0.42 & -1.71 & 0.18 & 0.1 \\
\hline \multicolumn{7}{|c|}{ Educational qualifications (comparator: none) } \\
\hline Below degree & 0.02 & 0.39 & 1.02 & 0.39 & 0.38 & 1.4 \\
\hline Degree & 1.00 & 0.48 & 2.71 & 1.00 & 0.48 & 2. \\
\hline \multicolumn{6}{|l|}{ Value scales } & \\
\hline Left-right & -0.12 & 0.12 & 0.88 & -0.54 & 0.12 & \\
\hline Libertn-authoritn. & $\underline{0.23}$ & $\underline{0.14}$ & $\underline{1.26}$ & 0.37 & 0.14 & \\
\hline
\end{tabular}

Coefficients in bold are significant at the 0.05 level or better; those underlined are significant between $0.05-0.10$. 
Table 16. Multinomial logistic regression of partisan preferences (comparator: Conservative)

\begin{tabular}{|c|c|c|c|c|c|c|}
\hline & \multicolumn{3}{|c|}{ Labour } & \multicolumn{3}{|c|}{ Liberal Democrat } \\
\hline & $\mathrm{b}$ & $\mathrm{SE}$ & Exp & $\mathrm{b}$ & $\mathrm{Se}$ & Exp \\
\hline Constant & 2.70 & 0.46 & & -0.51 & 0.71 & \\
\hline \multicolumn{7}{|l|}{ Age (comparator: $74+$ ) } \\
\hline $15-24$ & 1.93 & $\mathbf{0 . 3 7}$ & 6.87 & 0.25 & 0.56 & 1.29 \\
\hline $25-44$ & 1.02 & 0.29 & 2.76 & 0.68 & 0.41 & 1.96 \\
\hline $45-54$ & 0.71 & 0.30 & 2.04 & $\underline{0.23}$ & $\underline{0.43}$ & 1.26 \\
\hline $55-64$ & 0.34 & 0.29 & 1,40 & $\overline{0.07}$ & $\overline{0.42}$ & $\overline{1.08}$ \\
\hline $65-74$ & 0.17 & 0.29 & 1.19 & -0.17 & 0.43 & 0.84 \\
\hline \multicolumn{7}{|l|}{ Sex (comparator: female) } \\
\hline Male & -0.14 & 0.13 & 0.87 & -0.39 & 0.18 & 0.68 \\
\hline \multicolumn{7}{|l|}{ Ethnicity (comparator: BME) } \\
\hline White & -1.74 & 0.27 & 0.18 & -0.32 & 0.43 & 0.73 \\
\hline \multicolumn{7}{|c|}{ Educational qualifications (comparator: none) } \\
\hline Below degree & -0.77 & 0.27 & 0.46 & 0.20 & 0.40 & 1,22 \\
\hline Degree & -0.85 & 0.22 & 0.43 & 0.01 & 0.34 & 1.01 \\
\hline \multicolumn{7}{|c|}{ Housing tenure (comparator: rented) } \\
\hline Owner-occupied & -0.84 & 0.16 & 0.43 & -0.30 & 0.23 & 0.73 \\
\hline \multicolumn{7}{|c|}{ Occupational class (comparator: semi- and unskilled) } \\
\hline Professional & -0.71 & 0.19 & 0.49 & -0.52 & 0.26 & 0.59 \\
\hline Routine non-manual & -0.68 & 0.19 & 0.51 & -0.64 & 0.28 & 0.63 \\
\hline Skilled & -0.32 & 0.26 & 0.73 & -0.49 & 0.40 & 0.61 \\
\hline \multicolumn{7}{|c|}{ Trade Union (comparator: non-member) } \\
\hline Member & 0.76 & 0.17 & 2.15 & 0.30 & 0.23 & 1.34 \\
\hline \multicolumn{7}{|l|}{ Value scales } \\
\hline Left-right & -0.77 & 0.07 & 0.46 & -0.42 & 0.10 & 0.66 \\
\hline Libertrn.-authoritrn. & 0.66 & 0.08 & 1.93 & 0.86 & 0.10 & 2.37 \\
\hline \multicolumn{7}{|c|}{ Beliefs in climate change (comparator: believer) } \\
\hline Non-believer & -0.62 & 0.31 & 0.54 & -1.77 & 0.77 & 0.17 \\
\hline Believer but non-anthropo. & -0.55 & 0.19 & 0.58 & $\underline{-0.50}$ & $\underline{0.29}$ & $\underline{0.60}$ \\
\hline \multicolumn{7}{|c|}{ Concern and transport impact on climate change (comparator: not at all) } \\
\hline Very & 0.15 & 0.30 & 0.63 & 0.45 & 0.46 & 1.56 \\
\hline Fairly & 0.25 & 0.28 & 0.37 & 0.24 & 0.43 & 1.27 \\
\hline Not very & 0.09 & 0.28 & 0.97 & -0.23 & 0.45 & 0.80 \\
\hline
\end{tabular}

Coefficients in bold are significant at the 0.05 level or better; those underlined are significant between 0.05-0.10. 
